\title{
IMPLEMENTASI SISTEM PAKAR DIAGNOSA KERUSAKAN PADA CANON NP6650XX MENGGUNAKAN METODA DEMPSTER SHAFER
}

\author{
Khaerul Manaf \\ Jurusan Sistem Informasi Fakultas Teknik \\ Universitas Sangga Buana YPKP \\ khaerul.manaf@usbypkp.ac.id
}

\begin{abstract}
Abstrak - Sistem pakar adalah sebuah perangkat lunak komputer yang memiliki basis pengetahuan. Dimana pengetahuan diambil dari beberapa orang pakar dengan pengalamannya bekerja selama bertahun-tahun pada sebuah bidang keahlian tertentu. Sistem pakar lebih mudah dikembangkan dan spesifikasinya juga tidak terlalu sulit, sehingga dapat digunakan oleh komputerkomputer yang ada sekarang ini.
\end{abstract}

Kata kunci: Sistem Pakar, Pengetahuan, Mesin Canon, Error, Dempster Shafer.

\section{PENDAHULUAN}

Teknik pada komputer yang mampu melakukan pengolahan ilmu pengetahuan atau menirukan pola pikir seorang pakar disebut juga teknik kecerdasan buatan (Artificial Intelligence Technique). Sehingga dengan teknik ini komputer dapat dianggap sebagai pengganti seorang pakar dalam bidang tetentu. Hal ini akan memudahkan seorang pakar untuk melayani semua kebutuhan dari orang lain tanpa harus bertatap muka.

Teknik kecerdasan buatan yang paling populer saat ini adalah sistem pakar, dimana sistem pakar ini merupakan perangkat lunak komputer yang memiliki basis pengetahuan yang menyerupai seorang pakar dalam memecahkan suatu masalah. Dalam prosesnya pengguna dapat berkomunikasi secara interaktif dengan komputer untuk memenuhi informasi yang dibutuhkan, sehingga dapat memecahkan masalah dengan baik dan semaksimal mungkin.

Kebutuhan masyarakat akan dokumentasi tidak akan pernah terlepaskan dari kehidupan dan perkembangan. Perusahaan-perusahaan akan meletakan pendokumentasian ini sebagai suatu yang terpanting untuk meningkatkan dan mengembangkan kinerja dari perusahaan dan sebagainya. Jika pada perusahaan tersebut memerlukan duplikasi dokumentasi dengan pengoperasian yang mudah, dapat dilakukan pada canon NP 6650XX.

Pada kondisi tertentu bagi pengguna mesin canon NP 6650XX mungkin akan mengalami kesulitan untuk pengoperasian, misalkan terjadi kerusakan yang tidak dimengerti oleh pengguna yang berhubungan dengan penampilan error pada layar monitor panel. Pada manual book untuk canon NP 6650XX tidak memberikan langkah-langkah bagaimana menangani error tersebut. Cara menentukan jalan terbaik untuk menyelesaikan masalah yang didapat pada penggunaan canon NP 6650XX tanpa harus memanggil teknisi, maka dibuat pengaplikasian kode-kode yang mungkin keluar pada layar Canon NP6650XX sebagai suatu tanda kerusakan ke sebuah program yang berbasis komputer.

Tujuan dari penyusunan tugas akhir ini adalah membuat suatu perangkat lunak sistem pakar yang disebut dengan "IMPLEMENTASI SISTEM PAKAR DIAGNOSA KERUSAKAN PADA CANON NP6650XX MENGGUNAKAN METODA DEMPSTER SHAFER “ agar dapat membimbing pengguna atau teknisi apabila terdapat kesulitan untuk mengetahui kondisi dari mesin canon NP 6650XX yang berhubungan dengan penampilan error pada monitor dan juga dapat menentukan langkah-langkah apa yang harus dilakukan untuk menyelesaikannya. Bagi teknisi pemula juga dapat belajar dan memperluas pengetahuannya tentang error ini. Semua hal tersebut dapat dilakukan tanpa harus bertemu langsung dengan pakar atau ahli Canon NP 6650XX.

\section{TINJAUAN PUSTAKA}

\subsection{Kecerdasan Buatan (Artificial Inteligence)}

Intelijensia adalah kemampuan manusia untuk memperoleh pengetahuan-pengetahuan dan pandai melaksanakannya dalam praktek. Dalam hal ini adalah kemampuan dalam berpikir dan menalar, tujuan inilah yang ingin dicapai oleh suatu cabang ilmu kamputer yang disebut dengan Kecerdasan Buatan (Artificial Intelligence).

Sistem pakar (expert system) merupakan bidang kecerdasan buatan yang paling luas penerapannya. Bidang yang dicirikan oleh sistem yang berdasarkan pengetahuan (knowledge based system) ini memungkinkan komputer dapat berpikir dan mengambil kesimpulan dari sekumpulan kaedah (rule).

\subsection{Metode Dempster-Shafer}

Teori Dempster-Shafer pertama kalidiperkenalkan oleh oleh Arthur P. 
Dempster and Glenn Shafer, yang melakukan percobaan ketidakpastian dengan range probabilities daripada sebagai probabilitas tunggal. Kemudian pada tahun 1976 Shafer mempublikasikan teori Dempster pada buku yang berjudul Mathematichal Theory of Evident.Teori Dempster-Shafer merupakan teori matematika dari evidence. Teori tersebut dapat memberikan sebuah cara untuk menggabungkan evidence dari beberapa sumber dan mendatangkan atau memberikan tingkat kepercayaan (direpresentasikan melalui fungsi kepercayaan) dimana mengambil dari seluruh evidence yang tersedia. Secara umum Teori Dempster-Shaferditulis dalam suatu interval :

[Belief,Plausibility] Belief (Bel) adalah ukuran kekuatan evidence dalam mendukung suatu himpunan proposisi. Jika bernilai 0 maka mengindikasikan bahwa tidak ada evidence, dan jika m bernilai 1 menunjukkan adanya kepastian.

Plausibility (Pl) dinotasikan sebagai:

$$
\operatorname{Pl}(\mathrm{s})=1-\operatorname{Bel}(\neg \mathrm{s})
$$

Plausibility juga bernilai 0 sampai 1 . Jika kita yakin akan $-\mathrm{s}$, maka dapat dikatakan

bahwa $\operatorname{Bel}(\neg \mathrm{s})=1$, dan $\operatorname{Pl}(\neg \mathrm{s})=0$.

Plausability akan mengurangi tingkat kepercayaan dari evidence.

Pada teori Dempster-Shafer kita mengenal adanya frame of discernment yang dinotasikan dengan $\theta$ dan mass function yang dinotasikan dengan $\mathrm{m}$. Fungsi kombinasi $\mathrm{m} 1$ dan $\mathrm{m} 2$ sebagai $\mathrm{m} 3$ dibentuk dengan persamaan :

$$
\begin{aligned}
& M_{3}(Z)=\frac{\sum_{X \cap Y=Z} m_{1}(X) \cdot m_{2}(Y)}{1-K} \\
& \text { Dimana } \kappa=\sum_{X \cap Y=\varnothing} m_{1}(X) \cdot m_{2}(Y)
\end{aligned}
$$

Dengan :

$\mathrm{m} 1(\mathrm{X})$ adalah mass function dari evidence $\mathrm{X}$ $\mathrm{m} 2(\mathrm{Y})$ adalah mass function dari evidence $\mathrm{Y}$

$\mathrm{m} 3(\mathrm{Z})$ adalah mass function dari evidence

$\mathrm{Z}$

$\kappa$ adalah jumlah conflict evidence

\subsection{Komponen-komponen Sistem Pakar}

Setiap Sistem Pakar memiliki beberapa komponen yang sering disebut struktur sistem pakar Dalam sistem pakar ini yang merupakan bagian pentingnya adalah basis pengetahuan dan mesin inferensi.

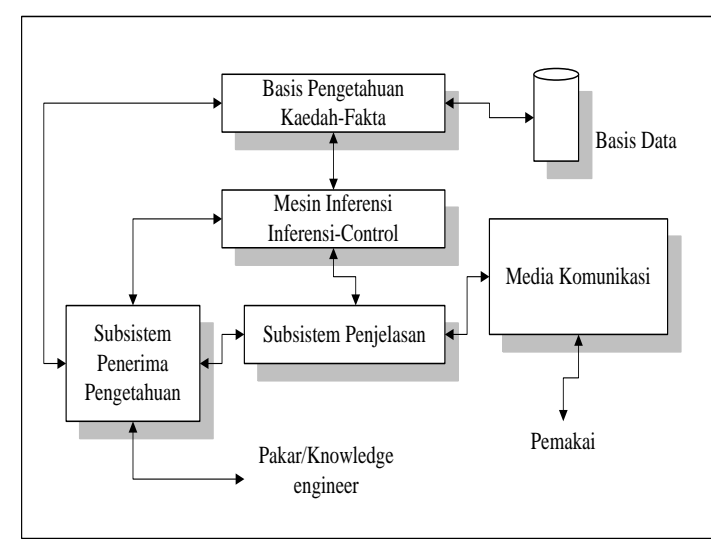

Gambar 2.1 Hubungan komponenkomponen utama sistem pakar.

\section{ANALISA SISTEM \\ 3.1 Permasalahan Pada Canon NP 6650XX}

Pendokumentasian pada saat ini merupakan suatu kebutuhan yang tidak terlepas dari kemajuan suatu perusahaan, jajaran pemerintahan, juga bagi masyarakat. Pada kemajuan teknologi yang sangat pesat ini berbagai mesin penduplikasian telah diproduksi oleh perusahaan-perusahaan elektronik dengan tipe yang berbeda-beda dan memiliki kelebihan yang berbeda-beda pula. Namun dalam berbagai tipe mesin penduplikasian tersebut ada satu tipe yang dalam pengoperasiannya mudah dan dalam pembiayaannya juga tidak terlalu mahal. Mesin ini juga memiliki feature yang lengkap, yang dapat melakukan penduplikasian standar dengan cepat dan hasil yang bagus, semua itu ada pada Canon NP 6650XX

Mesin ini banyak dipakai pada perusahaan yang memerlukan duplikasi dokumen dan banyak juga digunakan para pengusaha percetakan. Namun dalam pengoperasian mesin ini kadang kala user akan mendapat masalah yang kurang dimengerti berupa kode error

Jika masalah utama yang menimbulkan error tersebut tidak ada pada pengidupan mesin yang kedua kalinya, berkemungkinan mesin dapat dipakai kembali. Tapi ada juga kode error yang pada penghidupan yang kedua tidak terdapat masalah tapi masih menampilkan error pada layar monitor, dalam hal ini user akan mendapat kesulitan karena pada layar monitor hanya menampilkan code error tanpa menunjukan kepada user cara menangani dan langkah apa yang harus dilakukan user untuk memperbaikinya. Kode error juga tidak dilampirkan pada user manual book Canon NP 6650XX. Pada saat seperti ini user harus menghubungi teknisi dari mesin Canon NP 6650XX (service representative).

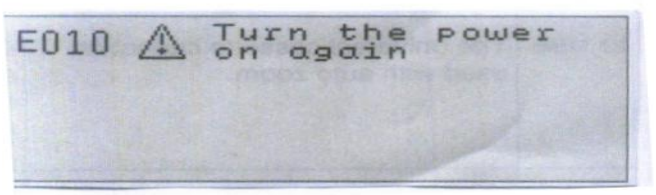

Gambar 3.1 Tampilan Error Code Pada Layar Monitor 


\subsection{Basis pengetahuan}

Basis pengetahuan pada sistem pakar dapat mempresentasikan keahlian seorang pakar dalam bidang apapun diantaranya diagnosa kerusakan pada Canon NP6650II. Basis pengetahuan memuat domain pengetahuan yang berhubungan dengan aspek "apa yang harus diketahui dari suatu obyek" . Basis pengetahuan diproses oleh program yang mengandung algoritma yang dibutuhkan.

Basis pengetahuan terdiri dari fakta-fakta dan aturan-aturan. Fakta adalah informasi tentang kondisi dari suatu obyek dalam sistem pakar. Aturan adalah informasi tentang bagaimana cara membangkitkan suatu fakta baru dari fakta yang diketahui.

Bentuk umum dari aturan yang terstruktur adalah :

IF Fakta1[and/or]

Fakta2[and/or]

\section{THEN fakta1}

Fakta1 dan Fạkta2 adalah fakta yang diketahui

Fakta1 adalah fakta baru yang dibangkitkan

\section{PERANCANGAN}

Perancangan sistem pakar ini merupakan tahapan yang paling utama. Proses yang dilakukan sesuai dengan tahapan umum pengembangan sebuah prototipe

Dalam menyelesaikan kendala-kendala yang terdapat pada Canon NP 6650XX maka diperlukan adanya suatu perangkat lunak yang dapat dipakai untuk berkonsultasi oleh user, melakukan tanya jawab langsung dengan sistem pakar untuk mendapatkan keterangan dari pakar dalam bidang tersebut tanpa harus bertamu langsung dengan pakarnya. Berdasarkan kebutuhan-kebutuhan dari user dalam penanganan mesin ini maka dibuat seatu rancangan basis pengetahuan yang merupakan implementasi dari sistem pakar. Rancangan untuk mengimplmentasikan sistem pakar ini tidak terlepas dari diagram arus data yang ada sebagai suatu acuan.

\subsection{Pengembangan Diagram Arus Data}

Diagram arus data merupakan sebuah gambaran cara kerja dari sistem pakar ini. Gambaran dari sistem ini menentukan dari dan kemana data akan mengalir secara terstruktur. Sehingga kita dapat melihat bagaimana sebuah sistem bekerja secara global.

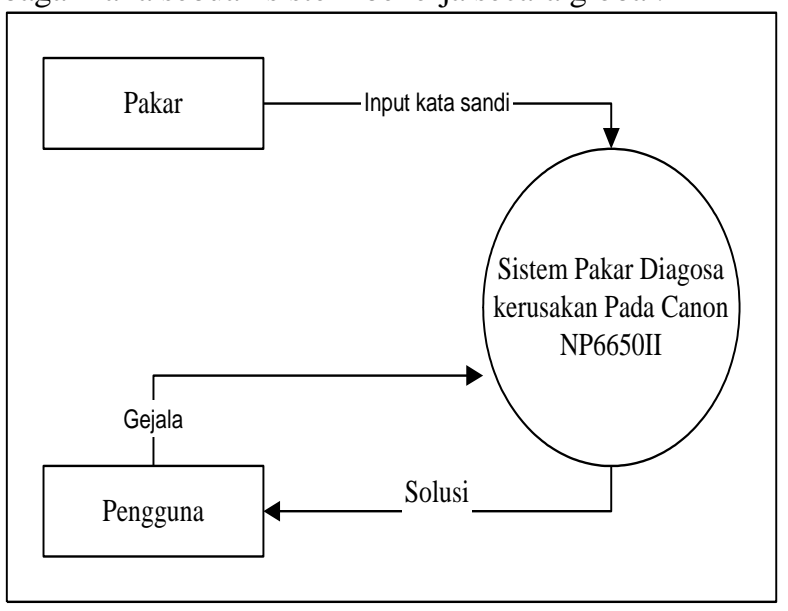

Gambar 4.1 Konteks Diagram
Diagram arus data ini dapat dikembangkan ke bentuk yang lebih detil dengan mengembangkan sistem pakar. Hasil pengembangan sistem akan menggambarkan proses apa saja yang terdapat dalam sistem pakar tersebut.

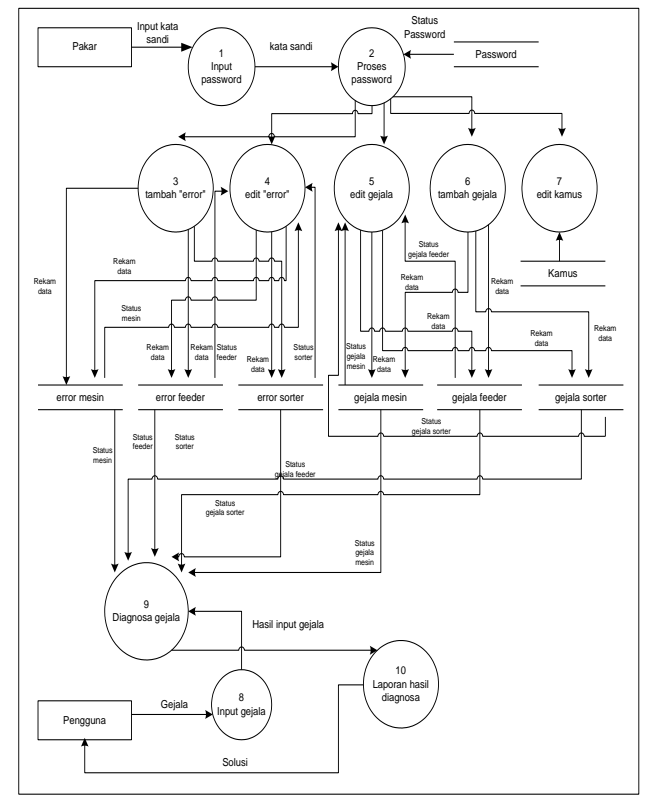

\section{Gambar 4.2 DFD level 1}

\subsection{Struktur Pohon Biner}

Struktur pohon biner menggambarkan secara hirarki pengendalian dan validasi fakta yang akan diseleksi. Apabila masuk ke cabang kiri berarti true (benar/valid) dan apabila masuk ke jalur kanan berarti false(salah/invalid).

Rancangan pohon biner ini akan mengawali pelacakan dari sekumpulan fakta-fakta menuju sebuah hipotesa yang merupakan solusi dari sekumpulan fakta tersebut. Teknik inferensi ini disebut forward chaining ( pelacakan kedepan) karena dalam pemecahannya dilakukan dengan mengumpulkan data lalu ditari kesimpulan. Teknik inferensi ini dipengaruhi oleh teknik penelusuran aturan depth-first search (DFS) yang merupakan teknik pencarian yang dilakukan secara mendalam mulai dari simpul dan selanjutnya akan menurun ketingkat yang berurutan.

\section{Gambar-gambar pohon biner :}

Keterangan istilah :

EM : Software pada mesin yang dapat diakses melalui penekanan tombol yang berada pada Jam Location Indicator yang berguna untuk pembangkitkan fungsi komponen-komponen dan juga bisa untuk meng-reset ulang. Software ini dapat menghilangkan kode error yang timbul setelah semua pengecekan terhadap kode error tersebut dalam kondisi yang benar. Hal ini dilakukan karena tidak semua kode error yang apabila pengecekan telah benar dan layar monitor masih menapilkan kode error. Jika hal ini terjadi maka pemakai harus mengakses 
software mesin ini dengan menekan tombol pada panel dengan terlebih dahulu menekan tombol pada Jam Location Indicator, dengan langkah : * - 4 -* - Up or Down - pilih kata "Error" - Paper select.

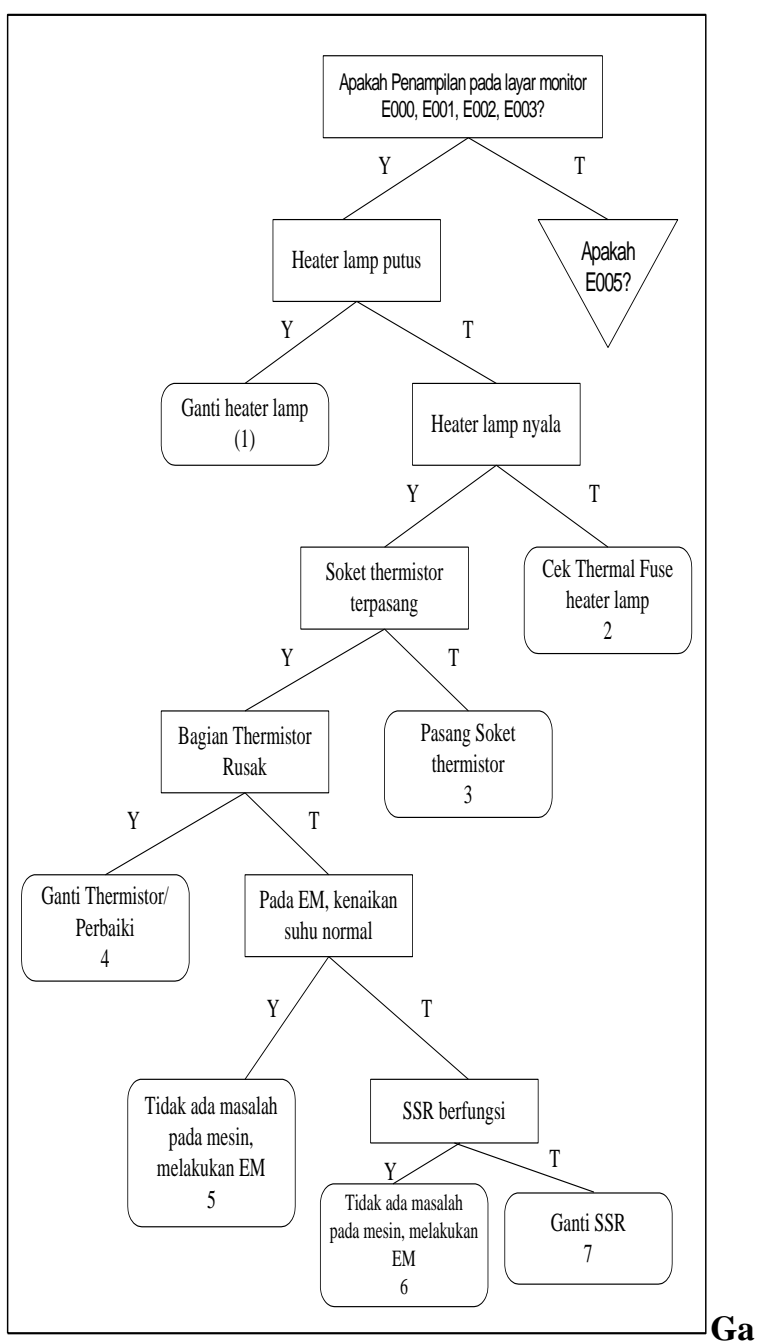

mbar 4.3 Penampilan (E000, E001, E002, E003) Canon NP 6650XX

Tabel 4.1 Deskripsi Utama Komponen Kerusakan Berdasarkan Kode Error Pada Mesin

\begin{tabular}{|c|c|c|c|c|c|c|c|c|c|c|c|c|c|c|c|c|c|c|c|c|c|c|c|}
\hline & \multicolumn{5}{|c|}{ Hatra } & \multicolumn{5}{|c|}{ W/sin Wotom } & \multicolumn{4}{|c|}{ Doples } & \multicolumn{3}{|c|}{ Hopper } & \multicolumn{3}{|c|}{ Sexts } & \multicolumn{3}{|c|}{ Lam } \\
\hline & \begin{tabular}{l|l}
$n \pi$ & 5
\end{tabular} & 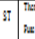 & & CII & $3 \pi$ & sones & 185 & & 5 & & $\mathrm{BD}$ & & & & $\mathrm{Wx}$ & & & & & 988 & 81 & $\sqrt{14}=$ & $n$ \\
\hline EOOO & $\sqrt{14}$ & $\sqrt{11}$ & $\sqrt{1}$ & $\cdot$ & $\cdot$ &. & . & $\cdot$ & . & - & . & & - & & $\cdot$ & & $\cdot$ & $\cdot$ & & . & $\cdot$ & $\cdot$ & \\
\hline EOOI & 11 & 11 & 1 & . & . & . & . & . & . & . & $\cdot$ & & . & & $\cdot$ & & & . & & $\cdot$ &. & $\cdot$ & \\
\hline $\mathrm{BOO2}$ & $\sqrt{11}$ & $\sqrt{11}$ & & . & . & . & & . & . & & . & & & & . & & & . & . & . & $\cdot$ & . & \\
\hline ED3 & 1 & & & . & . & & & . & & & . & & & & . & & & . & & . & . & - & \\
\hline $\mathrm{BOOS}$ & $\cdot$ & & $\cdot 1$ & $\sqrt{1}$ & 1 & 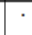 & . & $\cdot$ & $\cdot$ & . & . & & • & & $\cdot$ & & & . & & - & $\cdot$ & $\cdot$ & . \\
\hline ED10 & & & & $\cdot$ & . & $\sqrt{4}$ & 1 & 1 & 1 & $\sqrt{4}$ & . & & $\cdot$ & & • & & & $\cdot$ & ${ }^{\circ}$ & . & $\cdot$ & $\cdot$ & \\
\hline E020 & & & & & . & & & & & & & & & & $\sqrt{ }$ & & & - & & . & . & . & \\
\hline E050 & & & & & . & & & & & & 1 & & $\sqrt{1}$ & & & & & $\cdot$ & & . & $\cdot$ & - & \\
\hline E20: & & & - & & . & & & & & & & & & & & & & $\sqrt{1}$ & & 1 & $\cdot$ & - & \\
\hline 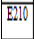 & & 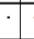 & . & & 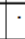 & & & & & & & & & & & & & · & & & 1 & $\sqrt{11}$ & \\
\hline
\end{tabular}

1. HT : Heater lamp
2. DDMM : DC Driver Main Motor

3. SW : Sensor Web

4. ST : Soket Thermistor

5. SHT : Soket Heater

6. $\quad \mathrm{CW}$ : Cleaning Belt/Web

7. MF : Main Motor Fuse

8. MS : Main Motor Soket

9. KM : Kabel Main Motor

10. GM : Gear Main Motor

11. KD : Kabel Duplex

12. MD : Motor Duplex

13. KSD : Kabel Sensor Duplex

14. SD : Sensor Duplex

15. MH : Motor Hopper

16. SH : Soket Hopper

17. SSH : Sensor Hopper

18. SMS : Soket Motor Scaner

19. MS : Motor Scaner

20. SS : Sensor Scaner

21. SBS : Scanbelt Scaner

22. RL : Rel Lensa

23. ML : Motor Lensa

24. SL : Sensor Lensa

25. PL : Penyangga Lens

Tabel 4.2 Deskripsi Utama Komponen Kerusakan Berdasarkan Kode Error Pada Feeder

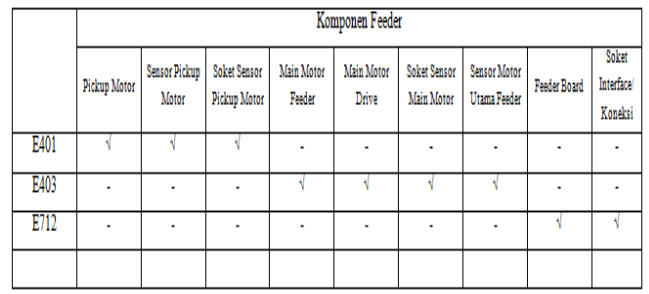

Tabel 4.3 Deskripsi Utama Komponen Kerusakan Berdasarkan Kode Error Pada Sorter

\begin{tabular}{|c|c|c|c|c|c|c|c|c|c|c|}
\hline & \multicolumn{10}{|c|}{ Kompunen Sotter } \\
\hline & 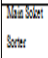 & int bus & $\lim 16 x x$ & $\begin{array}{l}\text { Brithin } \\
\text { Whor }\end{array}$ & 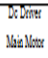 & 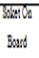 & $\begin{array}{c}\text { Bew } \\
\text { Bnath } \\
\text { Banh }\end{array}$ & $\begin{array}{l}\text { Bambinth } \\
\text { Band }\end{array}$ & 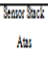 & \begin{tabular}{|c|} 
Bnath \\
Strithys
\end{tabular} \\
\hline E5OO & $\sqrt{ }$ & $\sqrt{1}$ & - & . & - & - & . & . & - & . \\
\hline Ej10 & $\cdot$ & - & $\sqrt{1}$ & t & $\sqrt{1}$ & $\sqrt{1}$ & . & - & - & \\
\hline E513 & $\cdot$ & - & $\sqrt{1}$ & $\sqrt{1}$ & $\sqrt{1}$ & $\sqrt{1}$ & . & - & - & · \\
\hline Ej40 & $\cdot$ & - & - & - & - & - & 1 & 1 & 1 & 1 \\
\hline E541 & $\cdot$ & . & . & . & . & . & $T$ & $\sqrt{1}$ & $\sqrt{1}$ & 1 \\
\hline
\end{tabular}

\section{IMPLEMENTASI}

Pada tahap ini implementasi dilakukan perumusan aturan-aturan untuk mewujudkan pengetahuan. Tahap implementasi ini melibatkan pemetaan pengetahuan yang telah disusun sebelumnya menuju penggambaran kerangka kerja dan dihubungkan dengan peralatan yang dipilih untuk masalah tersebut. 
Kegiatan yang dilakukan untuk mengimplementasikan sistem adalah : proses persiapan sistem kebutuhan perangkat keras dan perangkat lunak, implementasi program dan pengujian program.

\subsection{Proses Persiapan Sistem}

Proses persiapan sistem merupakan proses yang meliputi persiapan kebutuhan perangkat keras dan perangkat lunak.

Untuk membuat dan mengoperasikan sistem pakar diagnosa kerusakan pada canon NP 6650XX ini diperlukan perangkat keras dan perangkat lunak yang merupakan komponen yang saling menunjang.

Perangkat keras yang dipergunakan untuk membuat program ini diperlukan :

1. Core i3

2. Memory (RAM) 4GB.

3. VGA card $1 \mathrm{~GB}$

4. Monitor LED

5. Mouse dan Keyboard

6. Hardisk $500 \mathrm{~GB}$

Perangkat keras minimal yang dibutuhkan untuk menjalankan program ini adalah :

1. Minimal Pentium $233 \mathrm{Mhz}$

2. Memory (RAM) minimal $16 \mathrm{M}$.

3. VGA card $4 \mathrm{Mb}$ (True color)

4. Monitor SVGA

5. Mouse dan Keyboard

6. Hardisk $6.4 \mathrm{G}$

Disamping perangkat keras, diperlukan juga perangkat lunak untuk membuat dan mengoperasikan sistem pakar ini.

Perangkat lunak minimal yang diperlukan adalah :

1. Sistem operasi Windows $98 / \mathrm{Me}$

2. Bahasa pemrograman Delphi V 5.0

3. Adobe Photoshop dan Program aplikasi lainnya

\subsection{Implementasi Program}

Implementasi program merupakan kegiatan untuk mengoperasikan dan membuat kode-kode program sesuai dengan perancangan yang telah dilakukan pada tahap-tahap sebelumnya. Tahapan ini merupakan tahap pengembangan dari perancangan sistem yang telah dilakukan dimana knowledge engineer menerjemahkan bentuk hubungan antar unsur kedalam bahasa pemrograman.

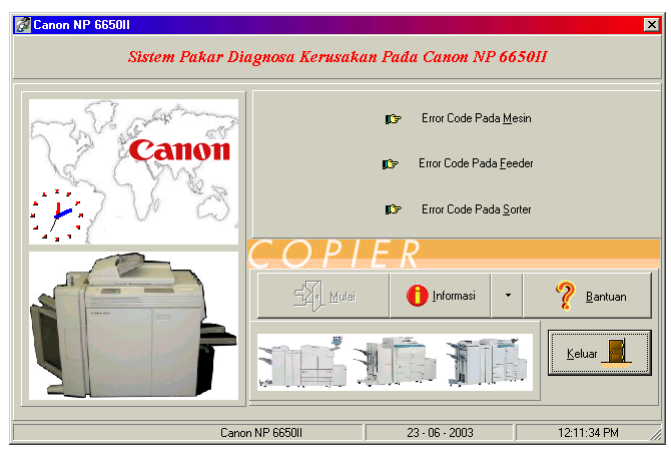

Gambar 5.1 Layar Utama Dari Sistem Pakar

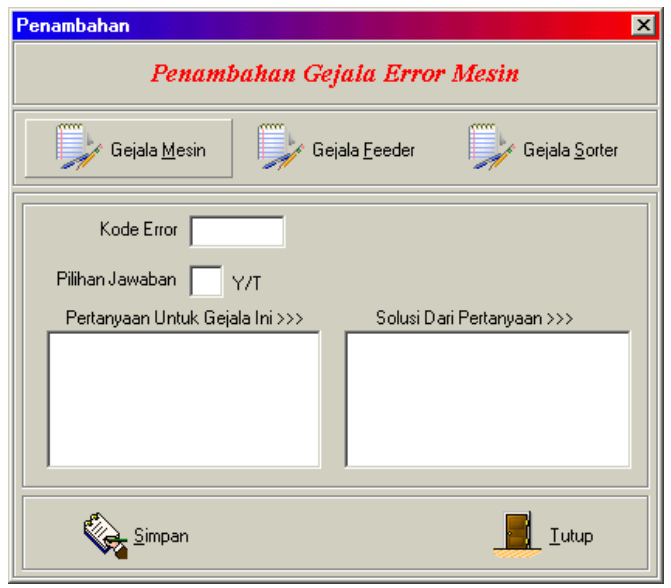

Gambar 5.1 Layar Tambah Gejala Lanjut

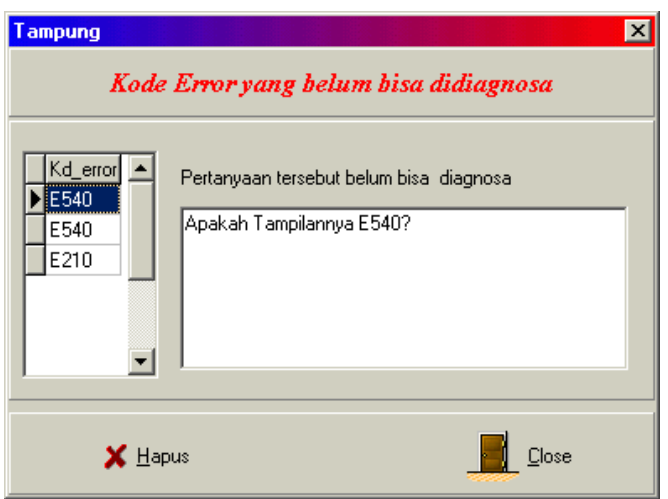

Gambar 5.3 Layar Penampungan Gejala Yang Tidak Bisa di Diagnosa

\subsection{Pengujian Program}

Tahapan selanjutnya dari pembuatan program sistem pakar ini adalah melakukan pengujian terhadap sistem yang dibangun. Pengujian tersebut sangat penting dilakukan untuk menguji apakah setiap pertanyaanpertanyaan tentang kode error pada canon NP 6650XX yang dimasukan sesuai dengan kesimpulan. Penampilan dialog antara sistem pakar dengan pemakai sistem apakah mudah untuk dipahami.

Program dibuat semaksimal mungkin untuk menghasilkan sebuah kesimpulan yang sesuai dengan gejala-gejala yang dimasukan. Oleh karena itu program harus diuji untuk menemukan kesalahan-kesalahan 
yang terdapat didalamnya. Pengujian tersebut juga berguna untuk melakukan perbaikan-perbaikan terhadap sistem pakar, mulai dari penampilan dialog sampai dengan penganaliasaan yang dilakukan oleh sistem.

\section{Kesimpulan}

Dengan Menggunakan Metoda Dempster Shafer maka diperoleh sebuah sistem pakar yang berguna untuk mendiagnosa kerusakan pada canon NP 6650XX berdasarkan kode error yang ditampilkan pada monitor mesin. Sistem ini dapat diperguanakan oleh teknisi pemula untuk mesin canon NP 6650XX juga bisa dijadikan tempat untuk belajar oleh orang yang memiliki mesin ini. Pada sistem pakar ini akan menampilkan solusi yang mudah dicerna oleh pengguna.

\section{Saran}

Untuk pengembangan sistem pakar diagnosa kerusakan pada canon NP 6650XX antara lain perlunya pengembangan sistem pakar ini berbasis Android atau Mobile agar sistem pakar ini dapat dipakai dimana saja dalam mendiagosa kerusakan pada mesin photo copy, dan juga tidak hanya terbatas untuk penampilan kode error saja, tapi bisa juga untuk pendiagnosaan paper jam dengan menampilkan simulasi dari cara kerja dari mesin ini.

Sistem harus bisa menampilkan hasil dari langkahlangkah diagnosa untuk diproses dalam pencetakan, sehingga user dapat melihat apa saja yang telah diproses selama pendiagnosaan yang telah dilakukan.

Metoda yang digunakan bisa menggunakan metoda yang lain tidak hanya menggunkan Metoda Dempster Shafer.

\section{REFERENSI}

1. [COM93] Canon Inc, Operator's Manual for Canon NP6650II, 1993.

2. [CSM93] Canon Inc, Service Manual for Canon NP6650II, 1993.

3. [EFR93] Efraim Turban, Expert system and Applied Artificial Inteligence, New York, 1993.

4. [WIN01] Wiwin Winiarti, Materi Sistem Pakar(Expert system), Bandung, 2001.

5. [SSR08] Sri Hartati dan Sari Iswanti, Sistem Pakar dan Pengembangannya, PT. Graha Ilmu, Jakarta, 2008.

6. [JAM91] James, Ignisio, Introduction to Expert System, Mc Graw Hill, Singapore, 2009.

7. [RSP97] Pressman R.S., Rekayasa Perangkat Lunak, Mc Graw-Hill edisi 7, 2012. 